University of Nebraska - Lincoln

DigitalCommons@University of Nebraska - Lincoln

Wildlife Damage Management Conferences -- $\quad$ Wildlife Damage Management, Internet Center Proceedings

2013

\title{
Regulated Commercial Harvest to Manage Overabundant White- tailed Deer: An Idea to Consider?
}

\author{
Scott E. Hygnstrom \\ University of Nebraska-Lincoln, shygnstrom1@unl.edu \\ Stephen M. VanTassel \\ University of Nebraska-Lincoln, stephenvantassel@hotmail.com \\ Timothy R. Van Deelen \\ University of Wisconsin - Madison \\ David Drake \\ University of Wisconsin - Madison
}

Follow this and additional works at: https://digitalcommons.unl.edu/icwdm_wdmconfproc

Hygnstrom, Scott E.; VanTassel, Stephen M.; Van Deelen, Timothy R.; and Drake, David, "Regulated Commercial Harvest to Manage Overabundant White-tailed Deer: An Idea to Consider?" (2013). Wildlife Damage Management Conferences -- Proceedings. 148.

https://digitalcommons.unl.edu/icwdm_wdmconfproc/148

This Article is brought to you for free and open access by the Wildlife Damage Management, Internet Center for at DigitalCommons@University of Nebraska - Lincoln. It has been accepted for inclusion in Wildlife Damage Management Conferences -- Proceedings by an authorized administrator of DigitalCommons@University of Nebraska - Lincoln. 


\title{
Regulated Commercial Harvest to Manage Overabundant White-tailed Deer: An Idea to Consider?
}

\author{
Scott E. Hygnstrom and Stephen M. Vantassel \\ School of Natural Resources, University of Nebraska, Lincoln, Nebraska \\ Timothy R. Van Deelen and David Drake \\ Department of Forest and Wildlife Ecology, University of Wisconsin, Madison, Wisconsin
}

\begin{abstract}
Dramatic growth in numbers of white-tailed deer (Odocoileus virginianus) and declines in hunter recruitment have challenged our ability to manage deer populations through traditional methods. We surveyed all state wildlife agencies and estimate the current abundance of white-tailed deer in North America exceeds 30 million. States currently are issuing record numbers of permits to hunters to increase harvest of white-tailed deer. Unfortunately, hunter participation has been declining in North America during the past two decades. Traditional methods of population management have been ineffective in reducing numbers of deer sufficiently in some environments. Regulated commercial harvest would help state wildlife agencies manage overabundant populations of white-tailed deer and allow licensed hunters to sell all or parts of harvested deer. We anticipate that many will criticize regulated commercial harvest of deer and claim that it is contrary to the North American Model of Wildlife Conservation (NAMWC). We feel, however, that regulated commercial harvest meets all seven of the pillars of the NAMWC:
\end{abstract}

1) Wildlife is a natural resource of the public trust (state wildlife agencies will manage deer and deer would continue to be a public resource).

2) No commercial use of wildlife [a direct reaction to exploitive and unsustainable market hunting in the $18^{\text {th }}$ and $19^{\text {th }}$ Centuries; commercial markets currently exist for other natural resources (e.g., furbearers, fish, timber); contemporary conservation values would not allow overexploitation; a framework for regulations, monitoring, and enforcement already is in place in every state].

3) Democratic rule of law to regulate use of wildlife (commercial harvest of white-tailed deer would be highly regulated by wildlife agencies through public processes).

4) Hunting opportunity for all (anyone legally able to hold a deer hunting license would be eligible to apply for a Commercial Deer Harvest License (CDHL), CDHL programs would be implemented only where recreational hunting is inefficient or inappropriate).

5) No frivolous use of wildlife (CDHLs will be used to generate food and other products, management would address risks to human health and safety and losses of agricultural resources to deer).

6) Wildlife is an international resource [has little to do with our proposed idea of managing overabundant resident populations of white-tailed deer, but a CDHL program may be applicable to any overabundant species, including internationally migratory species, such as snow geese (Chen caerulescens)].

7) Science-based wildlife policy (a CDHL program would rely on science and research-based data to estimate densities before, during, and after commercial harvest).

A CDHL program should be managed and distributed by state wildlife agencies, issue permits only to qualified individuals, enable harvest of an allotment of deer in areas targeted for population reduction, 
and permit the sale of whole carcasses and parts of harvested deer. Administration of a CDHL program will be taxing. State agencies are understaffed, but administrative and enforcement frameworks already exist for commercial harvest of publicly owned natural resources (e.g. furbearers, fish, timber) and the processing and handling of meat (e.g., USDA inspections). Revenue generated by CDHL programs could be directed back to agencies and personnel that administer and oversee programs. We anticipate several issues that must be addressed for regulated commercial harvest of deer to be accepted by agencies, hunters, and the public. State laws and regulations will need to be reviewed and some will have to be changed. Some will argue that we do not have the strength, stamina, or political will necessary to implement such broad sweeping changes. On the other hand, many wildlife managers will appreciate having an alternative tool for managing overabundant populations of white-tailed deer. Several benefits (reduce overabundant populations of deer; source of healthy, natural, green, locally-produced protein; economic growth, entrepreneurship, and market expansion; and public engagement and appreciation) and concerns (privatization of wildlife; overexploitation; food safety; competition with existing commodities; law enforcement; challenges of changing laws, regulations, and attitudes) are associated with this concept. We encourage a professional discussion of regulated commercial harvest to address the issue of overabundant white-tailed deer.

KEY WORDS: commercial harvest, population management, Odocoileus virginianus, overabundance, white-tailed deer, wildlife damage management

Proceedings of the $15^{\text {th }}$ Wildlife Damage Management Conference. (J. B. Armstrong, G. R. Gallagher, Eds). 2013. Pp. 9-10.

This paper has been published elsewhere and further details are available in the full paper, published as follows:

VERCAUTEREN, K.C., C.W. ANDERSON, T.R. VAN DEELEN, D. DRAKE, W.D. WALTER, S.M. VANTASSEL, and S.E. HYGNSTROM. 2011. Regulated commercial harvest to manage overabundant white-tailed deer: An idea to consider? Wildl. Soc. Bull. 35:185-194. 